\title{
Sex differences in the influence of toxoplasmosis on stress and perceived anxiety: Evidence for the stress-coping hypothesis
}

6 Jaroslav Flegr ${ }^{\text {a.* }}$ and Š́rka Kaňkováa.

7

8 a Division of Biology, Faculty of Science, Charles University, Prague, Viničná 7 ,

9 Prague 128 44, Czech Republic

14 Running head: Toxoplasmosis, stress and anxiety

$16 *$ Corresponding author:

17 Jaroslav Flegr

18 Division of Biology, Faculty of Science, Charles University, Prague, Czech Republic

19 Tel.: +(420) 221951821

20 e-mail: flegr@cesnet.cz

21

NOTE: This preprint reports new research that has not been certified by peer review and should not be used to guide clinical practice. 
medRxiv preprint doi: https://doi.org/10.1101/2022.01.24.22269770; this version posted January 25, 2022. The copyright holder for this preprint (which was not certified by peer review) is the author/funder, who has granted medRxiv a license to display the preprint in It is made available under a CC-BY-ND 4.0 International license .

\section{Abstract}

23 Life-long infection with Toxoplasma, which affects $30 \%$ of the human population, has specific behavioral effects. The stress-coping hypothesis explains why the toxoplasmosis-associated behavioral changes go in opposite directions in men and women. It suggests that toxoplasmosis impairs the health of humans, which results in chronic stress. Men and women are known to cope with stress in opposite ways. The first presumption of the hypothesis, impaired health, was confirmed in many studies. The second, higher level of stress, was tested only rarely. Levels of stress and anxiety, measured with the Perceived Stress Scale, and the State-Trait Anxiety Inventory X-2, respectively, were compared in a population of 614 Toxoplasma-free and 162 Toxoplasma-infected subjects. Higher stress was detected in the infected men, but not women. We also found that physical health had a positive rather than negative effect on stress when mental health is controlled, which seems to contradict the prediction of the stress-coping hypothesis. No differences were found in the anxiety of infected and noninfected subjects. Subjects who have objective reasons for stress (those with worse physical health) are less stressed than those without such reasons.

Keywords: Toxoplasma gondii; toxoplasmosis; anxiety; stress; stress-coping hypothesis.

\section{Introduction}

Latent toxoplasmosis, the lifelong infection by a protozoan parasite Toxoplasma gondii, affects about one-third of the world population (Tenter, Heckeroth, \& Weiss, 2000). It is associated with the occurrence of specific personality and behavioral traits, such as low novelty-seeking conscientiousness, higher emotional warmth in women, and lower warmth and higher suspiciousness in men, for review see, e.g., (Lindová, Př́íplatová, \&

47 Flegr, 2012). The intensity of many of these changes increases with time passed since the infection (Flegr, Kodym, \& Tolarová, 2000; Flegr, Zitkova, Kodym, \& Frynta, 
medRxiv preprint doi: https://doi.org/10.1101/2022.01.24.22269770; this version posted January 25,2022 . The copyright holder for this preprint (which was not certified by peer review) is the author/funder, who has granted medRxiv a license to display the preprint in It is made available under a CC-BY-ND 4.0 International license.

1996), suggesting that they represent the effects of the latent infection, not fading effects of a more dramatic but short phase of acute disease.

To explain the existence of many cumulative personality changes and especially to explain why these changes mostly go in the opposite direction in men and women, Lindová et al. suggested the so-called stress-coping hypothesis (Lindová, et al., 2010; Lindová, et al., 2006). According to this hypothesis, the latent Toxoplasma infection is associated with impaired health in infected subjects, which results in mild but long-term chronic stress. It is known that a sex-specific behavioral response to stress exists in humans. While men employ more individualistic and antisocial (e.g., aggressive, hostile) forms of coping (Carver, Scheier, \& Weintraub, 1989; Hobfoll, Dunahoo, BenPorath, \& Monnier, 1994), women under stress are more likely to seek and provide social support (Carver, et al., 1989; Rosario, Shinn, Mørch, \& Huckabee, 1988; Stone \& Neale, 1984), join with others (Hobfoll, et al., 1994), and verbalize towards others or the self (Tamres, Janicki, \& Helgeson, 2002). All behavioral changes that go in the opposite direction in the Toxoplasma-infected men and women, e.g., decreased extroversion, cooperativeness, and strength of superego in men and increase of these traits in women (Flegr \& Hrdý, 1994; Flegr, et al., 1996) can be explained in this theoretical framework.

The first presumption of the stress-coping hypothesis, namely impaired health of the subjects with latent toxoplasmosis, has been already confirmed in many studies (reviewed in (Flegr, Prandota, Sovickova, \& Israili, 2014)). However, the second presumption, the increased level of stress in Toxoplasma-infected subjects, has been tested only rarely. The only data suggesting a higher level of stress measured with a psychological instrument (DASS21 questionnaire) showed that the Toxoplasma-infected subjects scored higher in stress and probably also anxiety (Shirbazou, Abasian, \& 
medRxiv preprint doi: https://doi.org/10.1101/2022.01.24.22269770; this version posted January 25,2022 . The copyright holder for this preprint (which was not certified by peer review) is the author/funder, who has granted medRxiv a license to display the preprint in It is made available under a CC-BY-ND 4.0 International license.

74 Meymand, 2011). The infected subjects also expressed an increased level of the stress hormone cortisol and testosterone. This cross-sectional study was, however, performed on a relatively small population of 180 subjects, all of them being non-specified patients of Sina Hospital in Tehran. Another study showing an increased level of cortisol in Toxoplasma-infected subjects was performed in Sudan (Abdelazeem, Moddawe, Ahmed, \& Abdrabo, 2015). In this study, one hundred infected subjects, patients of a military hospital in Khartoum, had about two times higher concentrations of cortisol than 50 Toxoplasma-free controls (634 vs $324 \mathrm{nmol} / \mathrm{l})$. In contrast, no significant difference in the concentration of cortisol (but a trend in the right direction $p=0.077$ ) between infected and non-infected patients was observed in 120 schizophrenia patients in Egypt (El-Gebaly, et al., 2019).

A typical emotional response to long, mild, unpredictable stress is anxiety (Endler \& Parker, 1990). Many studies have shown the association between toxoplasmosis and the level of anxiety or the incidence of generalized anxiety disorder (Akaltun, Kara, \& Kara, 2018; Alvarado-Esquivel, et al., 2016; Bak, et al., 2018; Flegr \& Horáček, 2020; Groer, et al., 2011; Markovitz, et al., 2015; Suvisaari, Torniainen-Holm, Lindgren,

90 Harkanen, \& Yolken, 2017). However, even here some contradictory results exist (Gale, Brown, Berrett, Erickson, \& Hedges, 2014; Markkula, Lindgren, Yolken, \& Suvisaari, 2020).

The main purpose of the present study was to search for further evidence in favor or against the stress-coping hypothesis, namely evidence of the increased level of perceived stress in subjects infected with Toxoplasma. We used an electronic survey containing Perceived Stress Scale, and the State-Trait Anxiety Inventory X-2 to collect

97 personality and anamnestic data from a large sample of the nonclinical internet population individuals that were laboratory tested for toxoplasmosis. 
medRxiv preprint doi: https://doi.org/10.1101/2022.01.24.22269770; this version posted January 25,2022 . The copyright holder for this preprint (which was not certified by peer review) is the author/funder, who has granted medRxiv a license to display the preprint in It is made available under a CC-BY-ND 4.0 International license.

100 2. Material and methods

\subsection{Subjects}

The participants of the present study were recruited from members of the

103 Facebook and internet community Labbunnies and their Facebook friends using the

104 Facebook-based snowball method (Kankova, Flegr, \& Calda, 2015). They were invited

105 to do an internet test to learn how anxious and stressed they are in comparison to other

106 people. At the end of the questionnaire, they were informed that their data can be also

107 used for scientific purposes - the study of the relation between certain biological

108 factors, namely toxoplasmosis, contact with pets, and natural hair color with anxiety and

109 stress, and were provided the opportunity to ask for erasing their data. Less than $1 \%$

110 asked for this. All subjects got the information about their results in the tests and the

111 subjects with a very high level of anxiety or stress (top 5\% quantile) were recommended

112 to seek professional help. The study was conducted following relevant guidelines and

113 regulations.

\section{$114 \quad 2.2$ Questionnaire}

115 The questionnaire was operated on the Qualtrics platform. In the anamnestic part

116 of it, the respondents answered the questions about their age, sex, toxoplasmosis status,

117 and $\mathrm{Rh}$ phenotype (it is known for a long time that Rh-positive subjects are much more

118 resistant to adverse effects of latent toxoplasmosis than Rh-negative subjects, for review

119 see (Flegr, Novotná, Lindová, \& Havlíček, 2008; Flegr, Toman, Hula, \& Kankova,

120 2020)). Namely, they were asked to respond whether they had been laboratory tested for

121 toxoplasmosis and the result of this test (negative/positive-infected/I do not know, I am

122 not sure). They were reminded that toxoplasmosis is a parasite of cats that is especially

123 dangerous for pregnant women. The third response "I do not know, I am not sure" was 
medRxiv preprint doi: https://doi.org/10.1101/2022.01.24.22269770; this version posted January 25,2022 . The copyright holder for this preprint (which was not certified by peer review) is the author/funder, who has granted medRxiv a license to display the preprint in It is made available under a CC-BY-ND 4.0 International license.

124 checked in advance. Similarly, they were asked about their Rh blood group

125 (positive/negative/I do not know, I am not sure). They were reminded that Rh-negative

126 blood is the rarer variant, and the third response was checked in advance. The

127 participants were also asked to rate their physical conditions and mental conditions

128 using two six-point scales anchored with 1 - bad, 6 - excellent. The main parts of the

129 questionnaire were the Czech version of the 20-item self-report scale for anxiety

130 symptoms State-Trait Anxiety Inventory X-2 (STAI X-2) (Heretik, Ritomský, Novotný,

131 Heretik, \& Pečeňák, 2009), and 10-item self-report Perceived Stress Scale (PSS) as a

132 classic stress assessment instrument (Cohen \& Williamson, 1988). STAI X-2 measured

133 anxiety as a trait, respondents read the statements and choose how they feel generally.

134 Answers are recorded on a 4-point scale (almost never, sometimes, often, almost

135 always). The overall score may range from 20 to 80 , with a higher score indicating

136 greater anxiety. PSS finds out how often the respondent perceived the surrounding

137 events in the last month as unpredictable, uncontrollable, and stressful. Answers are

138 recorded on a 5-point scale (never, almost never, sometimes, quite often, very often).

139 Each item can contribute 0 to 4 points to an overall score, so the resulting score ranges

140 from 0 to 40 , with a higher score indicating a higher intensity of perceived stress.

\subsection{Statistics}

Between 28. 9. 2020 and 13. 4. 2021, the questionnaire was completed or partially

144 completed by 6000 subjects, 5200 of them during October and November 2020. We

145 filtered out all subjects who were younger than 18 , did not provide information about

146 toxoplasmosis or Rh phenotype, and skipped more than four questions in STAI or more

147 than two questions in PSS, or answered nearly all questions in STAI or PSS with the

148 same code. We calculated average anxiety and stress as the arithmetic means of answers 
medRxiv preprint doi: https://doi.org/10.1101/2022.01.24.22269770; this version posted January 25,2022 . The copyright holder for this preprint (which was not certified by peer review) is the author/funder, who has granted medRxiv a license to display the preprint in It is made available under a CC-BY-ND 4.0 International license .

149 of STAI and PSS questionnaires. These means were multiplied by the number of

150 questions in a particular questionnaire (20 in the case of STAI and 10 in the case of

151 PSS) to allow comparison to published data. The final data set contained data from 776

152 subjects who mostly completed both questionnaires. The set was uploaded to the public

153 repository Figshare doi.org/10.6084/m9.figshare.14651490.v1 (Flegr, 2021).

154 The effect of toxoplasmosis on anxiety and perceived stress was assessed both

155 with parametric (MANCOVA and ANCOVA) and nonparametric methods. Primarily

156 (for making our conclusions), we used the nonparametric method partial Kendall

157 correlation, which is not sensitive to the distribution of output variables, differences in

158 the number of subjects in particular groups, and the presence of outliers. Partial Kendall

159 correlation was computed in R 3.3.1 (R Core Team, 2018) using the package ppcor

160 (Kim, 2015) and our package of scripts Explorer 1.0

161 (https://doi.org/10.6084/m9.figshare.14685825.v1) (Flegr \& Flegr, 2021). All other tests

162 and descriptive statistics were done with the statistical package Statistica v. 10.0.

164 3. Results

\subsection{Descriptive statistics}

166 The final sample consisted of 776 subjects, 614 Toxoplasma-free (mean age 34.18, S.D.

167 11.37) and 162 Toxoplasma-infected (mean age 39.29, S.D. 10.57), the difference in age

168 was significant $\left(t_{774}=-5.16, p<0.0001\right)$. The difference in age between 138

169 Toxoplasma-free (mean age 34.96, S.D. 12.90) and 18 Toxoplasma-infected men (mean

170 age 40.17, S.D. 9.34) was not significant $\left(t_{154}=-1.66, p=0.100\right)$, while the difference

171 in age between 476 Toxoplasma-free (mean age 33.95, S.D. 10.89) and 144

172 Toxoplasma-infected women (mean age 39.01, S.D. 10.75$)$ was highly significant $\left(t_{627}=\right.$ 
medRxiv preprint doi: https://doi.org/10.1101/2022.01.24.22269770; this version posted January 25,2022 . The copyright holder for this preprint (which was not certified by peer review) is the author/funder, who has granted medRxiv a license to display the preprint in It is made available under a CC-BY-ND 4.0 International license.

$173-5.06, p<0.0001)$. The prevalence of toxoplasmosis was $11.54 \%$ in men and $23.23 \%$ in

174 women; this difference was again highly significant $\left(C h i^{2}=10.31, p=0.0013\right)$. In

175 contrast, the difference in the frequency of Rh-negativity between men $23.08 \%$ and

176 women $22.10 \%$ was not significant $\left(C h i^{2}=0.07, p=0.793\right)$. The prevalence of

177 toxoplasmosis was approximately the same in $173 \mathrm{Rh}$-negative (20.81\%) and $603 \mathrm{Rh}$ -

178 positive subjects $\left(20.90 \%,\left(C h \mathrm{i}^{2}<0.01, p=0.980\right)\right.$.

$179 \quad 3.2$ Influence of toxoplasmosis on anxiety and stress

180 The association between toxoplasmosis and the dependent variables anxiety and stress

181 was studied using multivariate analysis of covariance (MANCOVA) with

182 toxoplasmosis, sex, $\mathrm{Rh}$, and interactions toxoplasmosis-sex, $\mathrm{Rh}$-toxoplasmosis, and sex-

$183 \mathrm{Rh}$ as independent factors and age as a covariate. Only the effects of age $\left(F_{2,761}=26.04\right.$,

$184 p<0.0001)$ and toxoplasmosis-sex $\left(F_{2,761}=3.84, p=0.022\right)$ were significant. Very

185 similar results were provided in simplified models without toxoplasmosis-sex, or

186 toxoplasmosis-sex and Rh-sex interactions, or even the simplest model with only sex,

187 toxoplasmosis, and toxoplasmosis-sex interaction as the independent factors and age as

188 a covariate (age: $F_{2,763}=25.71, p<0.0001$; toxoplasmosis-sex: $F_{2,763}=3.84, p=0.022$ ).

189 In the following analyzes, we used the simplest model without $\mathrm{Rh}$ and $\mathrm{Rh}-$

190 toxoplasmosis interaction.

191 The follow-up univariate analysis of covariance (ANCOVA) performed separately

192 for anxiety or sex showed that neither toxoplasmosis nor toxoplasmosis-sex interaction

193 had a significant effect on anxiety $(p>0.82)$. On the other hand, toxoplasmosis-sex

194 interaction had a significant effect on stress $\left(F_{1,764}=6.17, p=0.013\right.$, eta $\left.a^{2}=0.008\right)$.

195 Figure 1 shows that the Toxoplasma-infected men, but not women had a higher level of

196 stress measured with PSS. Table 1 shows stress, anxiety, physical condition, and mental

197 conditions of particular groups of respondents. 
medRxiv preprint doi: https://doi.org/10.1101/2022.01.24.22269770; this version posted January 25,2022 . The copyright holder for this preprint (which was not certified by peer review) is the author/funder, who has granted medRxiv a license to display the preprint in perpetuity.

It is made available under a CC-BY-ND 4.0 International license .

198

199 Figure 1 Effect of toxoplasmosis on stress in men and women

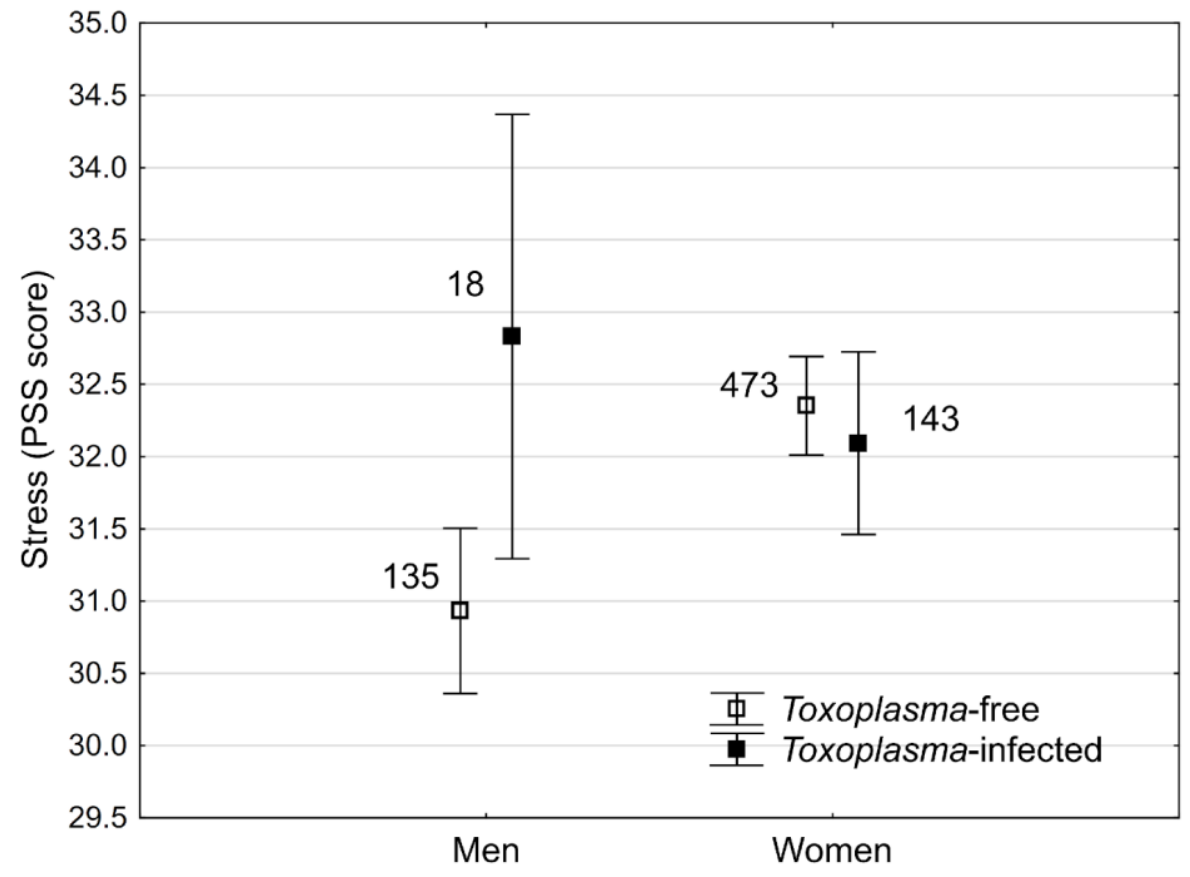

201 Vertical bars denote 0.95 confidence intervals, the squares show mean response computed for covariates at their means - i.e. for the age 35.2.

Table 1 Perceived stress, anxiety, physical health, and mental health of respondents

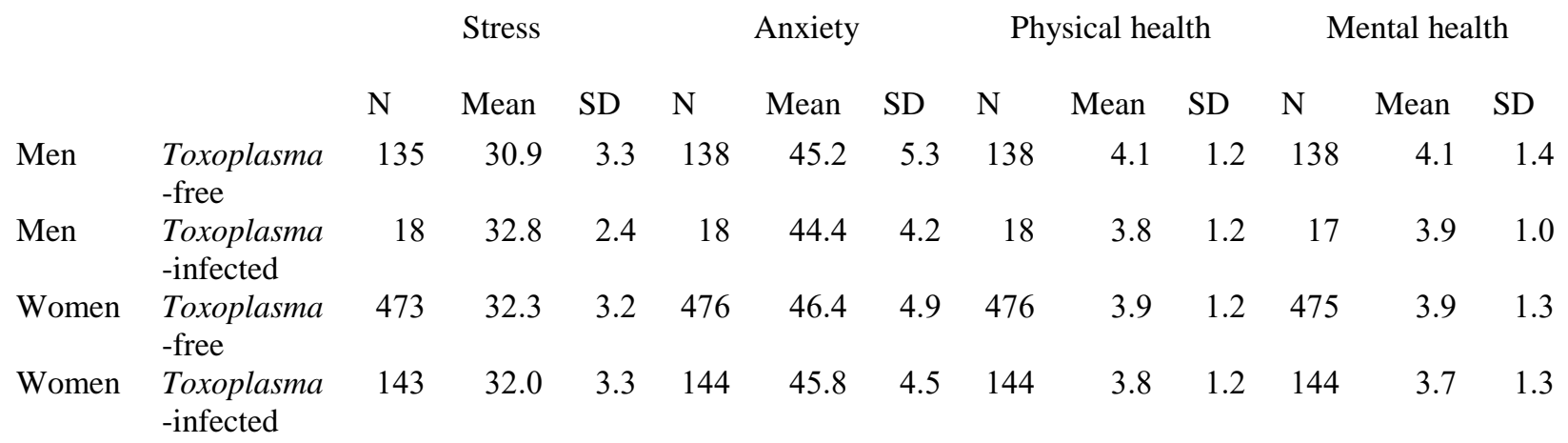

206 health of infected subjects. Therefore, we also included two other ordinal variables,

207 physical and mental health (higher scores mean better health) as covariates into the

208 analyzed models. The ANCOVA tests showed that higher anxiety was significantly associated with worse mental health $\left(F_{1,767}=110.88, p<0.0001\right.$, eta $^{2}=0.126$, beta $=$ - 
$2100.384)$ and lower age $\left(F_{1,767}=24.40, p<0.0001\right.$, et ${ }^{2}=0.031$, beta $\left.=-0.165\right)$, but not

with physical health $\left(F_{1,767}=0.235, p=0.638, e t a^{2}=0.0003\right.$, beta $\left.=0.017\right)$ or

toxoplasmosis $\left(F_{1,767}=0.345, p=0.557\right.$, eta $^{2}=0.0005$, beta $\left.=0.030\right)$, or the

213 toxoplasmosis-sex interaction $\left(F_{1,767}=0.027, p=0.870\right.$, eta ${ }^{2}<0.0003$, beta $\left.=-0.010\right)$.

214 In contrast, higher stress covaried with worse mental health $\left(F_{1,760}=90.403, p<0.0001\right.$,

$215 e t a^{2}=0.106$, beta $\left.=-0.362\right)$, better physical health $\left(F_{1,760}=5.201, p=0.023\right.$, eta $^{2}=$

2160.007$, beta $=0.086)$ and the toxoplasmosis-sex interaction $\left(F_{1,760}=7.444, p=0.007\right.$,

217 eta ${ }^{2}=0.010$, beta $\left.=-0.168\right)$, but not age $\left(F_{1,760}=2.776, p=0.098\right.$, eta ${ }^{2}=0.004$, beta $=$

$2180.05)$ or toxoplasmosis $\left(F_{1,760}=2.747, p=0.094\right.$, eta ${ }^{2}=0.004$, beta $\left.=-0.087\right)$. The

219 correlation of stress with physical health was positive when mental health was

220 controlled in this full model. However, in a simplified model not containing the

221 covariate mental health, this correlation was negative - i.e., the subjects with worse

222 physical health expressed a higher level of stress $\left(F_{1,761}=3.962, p=0.047\right.$, eta $^{2}=0.005$,

223 beta $=-0.071)$.

\subsection{Sex differences in the influence of toxoplasmosis on anxiety and stress}

225 To examine the nature of the toxoplasmosis-sex interaction we analyzed men and women separately with partial Kendall tests. The results showed that toxoplasmosis correlated with stress in men $(\mathrm{Tau}=0.179, p=0.001)$ but not in women $($ Tau $=-0.028$, $p=0.304)$; no association between toxoplasmosis and anxiety was significant. Separate analyses for Rh-positive and Rh-negative men showed that the toxoplasmosis-stress

230 association was of similar strength in Rh-positive men (Tau $=0.174, p=0.005)$ and $\mathrm{Rh}$ negative men $(T a u=0.190, p=0.115)$, however, the association was significant only in more numerous Rh-positive men (118 vs 35). Separate analyses for Rh-positive and Rh-

233 negative women showed no significant association between toxoplasmosis and stress

234 (both $p$ values > 0.272). Analogical separate analyses for Rh-positive and Rh-negative 
medRxiv preprint doi: https://doi.org/10.1101/2022.01.24.22269770; this version posted January 25,2022 . The copyright holder for this preprint (which was not certified by peer review) is the author/funder, who has granted medRxiv a license to display the preprint in It is made available under a CC-BY-ND 4.0 International license.

235 subjects found no significant effect of toxoplasmosis on anxiety in men or women (all $p$ 236 values $>0.360)$.

\section{$237 \quad 3.4$ Association of mental and physical health with anxiety and stress}

238 Partial Kendall correlation controlled for age or age and sex showed that worse mental

239 health correlated strongly with anxiety and stress in both men and women (anxiety men:

240 Tau $=-0.363$, stress men: Tau $=-0.331$, anxiety women: Tau $=-0.271$, stress women:

$241 T a u=-0.231$, all $p<0.0001)$. Worse physical health was correlated only with higher

242 anxiety in women $(\mathrm{Tau}=-0.101, p=0.0002)$. Partial Kendall correlation also showed

243 that anxiety positively correlated with stress (men: Tau $=0.375, p<0.0001$; women:

244 Tau $=0.290, p<0.0001)$.

\subsection{Association between latent toxoplasmosis and mental respectively physical}

246 health

247 Toxoplasmosis correlated significantly with mental health in women $(\operatorname{Tau}=-0.065, p=$

$2480.015)$ but not in men $(\operatorname{Tau}=-0.074, p=0.171)$. Further analyses split by $\mathrm{Rh}$

249 phenotype, however, showed that the negative association between toxoplasmosis and 250 mental health was significant only in Rh-negative subjects (Rh-negative women: Tau= $-0.131, p=0.025 ; \mathrm{Rh}$-positive women: $\operatorname{Tau}=-0.049, p=0.111)$. The association between toxoplasmosis and mental health was of a similar strength in Rh-negative women and Rh-negative men (women: Tau $=-0.131$; men: Tau $=-0.136$ ) but achieved a

254 level of statistical significance only in more numerous women (women: $p=0.025, n=$

255 137; men: $p=0.251, n=36$ ). In Rh-positive subjects the strength of the toxoplasmosismental health association was weaker in women than in men (women: Tau $=-0.049$; men: Tau $=-0.064$ ), but was significant neither in women, nor men (women: $p=0.111$, $\mathrm{N}=483$; men: $\mathrm{p}=0.301, \mathrm{~N}=119)$. The association between toxoplasmosis and 
medRxiv preprint doi: https://doi.org/10.1101/2022.01.24.22269770; this version posted January 25,2022 . The copyright holder for this preprint (which was not certified by peer review) is the author/funder, who has granted medRxiv a license to display the preprint in It is made available under a CC-BY-ND 4.0 International license.

259 physical health was significant neither in women (Tau $=-0.018, p=0.509)$ nor men

260 (Tau $=-0.052, p=0.334)$. No significant association between toxoplasmosis and

261 physical health was revealed in the analyses split by Rh-phenotype (all $p$ values >

$2620.139)$.

\section{4. Discussion}

264 We found a significant association between perceived stress measured with PSS and

265 toxoplasmosis-sex interaction and no association between anxiety measured with STAI

266 X-2 and toxoplasmosis. Toxoplasma-infected men had a significantly higher level of

267 stress while Toxoplasma-infected women had a non-significantly lower level of stress

268 than corresponding Toxoplasma-free controls. We found no effect of Rh factor

269 phenotype or its interaction with toxoplasmosis on anxiety or stress. The effect of

270 toxoplasmosis on stress was not mediated by impaired physical or mental health conditions as it was even stronger when the effect of physical and mental health was controlled. In accordance with the bulk of previous results (Flegr \& Escudero, 2016;

273 Flegr \& Horáček, 2020; Flegr, et al., 2014; Šebánková \& Flegr, 2017), toxoplasmosis

274 was associated with impaired health, here mental health, only in Rh-negative subjects.

275 The increased level of stress in male participants is in an accord with the

276 predictions of the stress-coping hypothesis (Lindová, et al., 2010; Lindová, et al., 2006).

277 The authors of this hypothesis theorized that many behavioral changes observed in

278 Toxoplasma-infected subjects are in fact results of mild but long-lasting stress - the

279 result of their impaired health. The impaired health of the Toxoplasma-infected subjects

280 was observed in several already published studies (Flegr \& Escudero, 2016; Flegr \&

281 Horáček, 2020; Flegr, et al., 2014; Flegr, et al., 2020; Šebánková \& Flegr, 2017) and

282 was confirmed by this study too. The present study has also brought evidence for an

283 increased level of perceived stress in men with latent toxoplasmosis. There are, 
medRxiv preprint doi: https://doi.org/10.1101/2022.01.24.22269770; this version posted January 25, 2022. The copyright holder for this preprint (which was not certified by peer review) is the author/funder, who has granted medRxiv a license to display the preprint in It is made available under a CC-BY-ND 4.0 International license.

284 however, two problems that complicate the straightforward interpretation of the results 285 of the present study in favor of the stress-coping hypothesis:

286 First, we did not detect increased stress in women. We can just speculate that the

287 PSS questionnaire, which measures the level of perceived stress rather than the level of 288 real physical stress, better reflects the level of stress in men than in women. Such a

289 gender difference could explain why the correlation between anxiety and stress was

290 stronger in men than in women (0.375 vs. 0.290), however, no independent support for

291 this idea probably exists in scientific literature.

292 Second, the effect of toxoplasmosis on stress measured with PSS was even more

293 visible when the effect of impaired mental and physical health was controlled. The

294 results even suggest that better physical health results in lower stress when the covariate 295 mental health is controlled, suggesting that those subjects who have objective reasons

296 for stress (here those with worse physical health) are less stressed than those without

297 such reasons.

298 We have no explanation as to why we found an effect of toxoplasmosis on stress

299 but not on anxiety. Anxiety is the most typical emotional response to long, mild, non-

300 predictable stress, including physical stress (Shin \& Liberzon, 2010). A fundamental

301 distinction exists between state anxiety, which is a transitory emotional condition, and

302 which is measured with STAI X-1, and trait anxiety, which is a stable personality

303 characteristic regarding the potential for manifesting state anxiety and which is

304 measured with the STAI X-2 (Endler \& Parker, 1990). We searched for a long-term

305 attunement of participants in the study and not for a transient state at the time of

306 participation in the study. Therefore, we expected that the personality trait anxiety

307 would better discriminate between Toxoplasma-infected and Toxoplasma-free subjects.

308 It is possible that this approach was not optimal - the trait anxiety might be determined 
medRxiv preprint doi: https://doi.org/10.1101/2022.01.24.22269770; this version posted January 25,2022 . The copyright holder for this preprint (which was not certified by peer review) is the author/funder, who has granted medRxiv a license to display the preprint in It is made available under a CC-BY-ND 4.0 International license .

309 mostly genetically or might crystalize early in the development of human personality

310 and cannot be affected later by acquired infection.

311 In contrast to most previous results (Flegr, Novotná, Fialová, Kolbeková, \&

312 Gašová, 2010; Flegr, et al., 2008; Flegr, Sebankova, Priplatova, Chvatalova, \&

313 Kankova, 2018; Kaňková, Šulc, \& Flegr, 2010; Novotná, et al., 2008), we did not find

314 an effect of toxoplasmosis-Rh interaction on anxiety and stress. We only confirmed this

315 effect on mental health, as the association between toxoplasmosis and mental health was

316 detected only in Rh-negative subjects. About 15 published studies have shown that Rh-

317 negative subjects are more prone to the adverse effects of toxoplasmosis as well as to

318 other negative factors, such as aging, smoking, and fatigue (Flegr, Geryk, Volny, Klose,

319 \& Cernochova, 2012; Kaňková, et al., 2010). A recent study, however, showed that Rh-

320 positive heterozygotes have superior health and performance while $\mathrm{Rh}$-positive

321 homozygotes have, in many respects, worse performance than Rh-negative subjects

322 (Flegr, et al., 2020). It is possible to study the effects of Rh-phenotype with an

323 electronic questionnaire method, as a large fraction of people know whether they have

324 Rh-positive or Rh-negative blood. In contrast, only a negligible number of people know

325 whether they are Rh-positive heterozygotes or homozygotes. This can be recognized

326 only by molecular genotyping. It would be therefore useful to repeat this study with a

327 genotyped population. However, it will be rather difficult and expensive to genotypize a

328 large enough population of volunteers.

329 It was suggested in the past that observed behavioral differences between the

330 infected and non-infected subjects are the cause, rather than the effect of the

331 Toxoplasma infection (Robertson, 1965). The results of longitudinal studies (Flegr, et

332 al., 2000; Flegr, et al., 1996) as well as the observation of analogical changes in the

333 behavior of artificially infected laboratory rodents (Hodková, Kodym, \& Flegr, 2007; 
medRxiv preprint doi: https://doi.org/10.1101/2022.01.24.22269770; this version posted January 25,2022 . The copyright holder for this preprint (which was not certified by peer review) is the author/funder, who has granted medRxiv a license to display the preprint in It is made available under a CC-BY-ND 4.0 International license.

334 Skallová , Kodym, Frynta, \& Flegr, 2006; Vyas, Kim, Giacomini, Boothroyd, \&

335 Sapolsky, 2007; Vyas, Kim, \& Sapolsky, 2007) demonstrated that this explanation

336 cannot be valid. It is not clear, however, whether observed behavioral and personality

337 changes are (1) the products of the manipulative activity of Toxoplasma aimed to

338 increase the chances of transmission from intermediate to definitive host, or (2) the side

339 effects of other manipulative activities of Toxoplasma aimed to suppress or redirect

340 immune reactions of the infected host, or (3) side-effects of pathological processes

341 running in the infected organism, or (4) the adaptive or (5) maladaptive reactions of the

342 host to the parasitic infection. It is highly probable that all of these alternatives are valid

343 and can explain specific differences in the behavior and personality between infected

344 and non-infected humans, for the detailed discussion of the topic see (Flegr, 2013).

345 Theoretically, some unknown factors affecting the probability of Toxoplasma

346 infection, e.g. inborn or acquired immunodeficiency, could be responsible for the

347 association between stress or anxiety and toxoplasmosis. This possibility cannot be

348 excluded by any observational study, but only by an experiment - artificial infection of

349 randomly selected hosts. Such experiments cannot be done on humans. There are,

350 however, many results from studies performed on laboratory rodents showing that the

351 toxoplasmosis-associated behavioral changes, including stress and anxiety are caused

352 by the infection, not by some other factor.

353 The main limitation of the present study was that the participants were self-

354 selected and therefore they did not represent a typical Czech population. This is a more

355 or less serious problem of all studies conducted in accord with the Declaration of

356 Helsinki, i.e., in all studies in which the participants are informed that their involvement

357 is voluntary, and they can decline to participate in it at any time. It is always necessary 
medRxiv preprint doi: https://doi.org/10.1101/2022.01.24.22269770; this version posted January 25,2022 . The copyright holder for this preprint (which was not certified by peer review) is the author/funder, who has granted medRxiv a license to display the preprint in It is made available under a CC-BY-ND 4.0 International license.

358

360

361

362

363

364

365

366

367

368

369

370

371

372

375

376

377

380

381

to keep in mind that the conclusions of studies might hold for a specific segment of population, not for the general population as a whole.

The participants also reported their toxoplasmosis status and Rh-phenotype

themselves. In the previous internet study (Flegr, 2017), we checked the toxoplasmosis status provided by 3,827 participants who had been examined in our laboratory within the past 10 years. We found $99.5 \%$ correspondence of the information provided by the participants and that recorded in our database (Flegr, 2017). However, about $60 \%$ of male and $70 \%$ of female participants recruited by the Facebook-based snowball method were tested for toxoplasmosis elsewhere, mostly in relation to their health problems (49.4\% of men), or to their pregnancy (37.6\% of women) (Flegr \& Preiss, 2019). It is highly probable that some subjects misreported whether they are Toxoplasma-infected (or Rh-negative) or not. Similarly, some respondents who were Toxoplasma-negative during their serological test could have acquired the infection in the time between the serological test and participation in the present study. It is, however, important to remember that the presence of misdiagnosed subjects in the population can result in a Type 2, not a Type 1 error - it can increase the risk of failure to detect existing effects but not the risk of detecting non-existing effects. Theoretically, the stochastic errors could explain the negative result of the test searching for the effect of toxoplasmosis on anxiety. However, we consider this possibility rather improbable as we find a negative, rather than positive, relation between toxoplasmosis and anxiety.

The size of the observed effects of toxoplasmosis on stress might seem relatively low. However, the Kendall Tau 0.190 corresponds to Cohen d 0.31, which is usually classified halfway between small and medium effects.

\section{Conclusions}


medRxiv preprint doi: https://doi.org/10.1101/2022.01.24.22269770; this version posted January 25, 2022. The copyright holder for this preprint (which was not certified by peer review) is the author/funder, who has granted medRxiv a license to display the preprint in It is made available under a CC-BY-ND 4.0 International license.

383 In the present study, we showed that Toxoplasma-infected men had a higher level of

384 perceived stress than Toxoplasma-free men. At face value, this observation provides

385 new support for the stress-coping hypothesis explaining the reason why the

386 toxoplasmosis-associated personality and behavioral shifts go mostly in opposite

387 directions in men and women. However, the absence of this effect in women, as well as

388 the negative effect of physical health problems on the level of stress (when mental

389 health is controlled) indicates that we must be careful with the interpretation of new

390 results. Possibly, we should also rethink whether perceived stress correctly reflects the

391 real level of physical stress. Generally, our results suggest that direct measurement of

392 the concentration of stress hormones might be a better approach for testing the stress-

393 coping hypothesis than measuring perceived stress using psychological instruments.

394 The effect of latent toxoplasmosis on the health of people was not the topic of

395 the present study. Still, the increased level of perceived stress in men, as well as worse

396 mental health in Toxoplasma-infected Rh-negative men and women, brought the new

397 evidence that toxoplasmosis (affecting one-third of the human population) could be a

398 serious and underestimated public health problem.

399

400 Acknowledgments: We would like to thank Lincoln Cline for her help with preparing

401 the final version of the article.

402

403 Statement of Ethics: The project, including the method of obtaining informed consent

404 to participate in this anonymous study from all participants by pressing the

405 corresponding button on the first page of the questionnaire, was approved by the IRB of

406 the Faculty of Science, Charles University (Komise pro práci s lidmi a lidským

407 materiálem Př́rodovědecké Fakulty Univerzity Karlovy) — No. 2019/30.

408 
medRxiv preprint doi: https://doi.org/10.1101/2022.01.24.22269770; this version posted January 25,2022 . The copyright holder for this preprint (which was not certified by peer review) is the author/funder, who has granted medRxiv a license to display the preprint in It is made available under a CC-BY-ND 4.0 International license .

409 Conflicts of Interest: The authors declare no conflict of interest.

410

411 Funding Sources: This research was funded by Czech Science Foundation, grant

412 number $18-13692 \mathrm{~S}$.

413

414 Author Contributions: Conceptualization, original draft preparation, funding

415 acquisition, and supervision, J.F.; formal analysis, writing—review and editing,

416 investigation J.F. and Š.K. Both authors have read and agreed to the published version

417 of the manuscript.

418

419 Data Availability Statement: All data are available at Fishare repository,

420 doi.org/10.6084/m9.figshare.14651490.v1 (Flegr, 2021)

421 


\section{References}

Abdelazeem, H., Moddawe, G., Ahmed, A. S., \& Abdrabo, A. A. (2015). Assessment of level of cortisol hormone in patients with toxoplasmosis. International Journal of Science and Research, 4, 55-57.

Akaltun, I., Kara, S. S., \& Kara, T. (2018). The relationship between Toxoplasma gondii IgG antibodies and generalized anxiety disorder and obsessive-compulsive disorder in children and adolescents: a new approach. Nordic Journal of Psychiatry, 72, 57-62.

Alvarado-Esquivel, C., Sanchez-Anguiano, L. F., Hernandez-Tinoco, J., BerumenSegovia, L. O., Torres-Prieto, Y. E., Estrada-Martinez, S., Perez-Alamos, A. R., Ortiz-Jurado, M. N., Molotla-de-Leon, G., Beristain Garcia, I., Rabago-Sanchez, E., \& Liesenfeld, O. (2016). Toxoplasma gondii infection and mixed anxiety and depressive disorder: A case-control seroprevalence study in Durango, Mexico. $J$ Clin Med Res, 8, 519-523.

Bak, J., Shim, S. H., Kwon, Y. J., Lee, H. Y., Kim, J. S., Yoon, H., \& Lee, Y. J. (2018). The association between suicide attempts and Toxoplasma gondii infection. Clinical Psychopharmacology and Neuroscience, 16, 95-102.

Carver, C. S., Scheier, M. F., \& Weintraub, J. K. (1989). Assessing coping strategies A theoretically based approach. Journal of Personality and Social Psychology, $56,267-283$.

Cohen, S., \& Williamson, G. (1988). Perceived stress in a probability sample of the United States. In S. Spacapan \& S. Oskamp (Eds.), The social psychology of health: Claremont Symposium on applied social psychology (pp. 31-67). Newbury Park, CA: Sage.

El-Gebaly, N. S. M., Abd-Eltawab, M. S. A., Hamed, A. M. R., Mahfouz, N. A., Abdelmaksoud, R., Adel, S., Mahfoz, A. M., Rehan, M. K., \& Elsebaei, E. H. (2019). Insights into the interplay of latent toxoplasmosis, testosterone, cortisol and oxidative stress in screened schizophrenic patients in Egypt. Parasitologists United Journal, 12, 102-109.

Endler, N. S., \& Parker, J. D. A. (1990). Stress and anxiety - Conceptual and assessment issues. Stress Medicine, 6, 243-248.

Flegr, J. (2013). Influence of latent Toxoplasma infection on human personality, physiology and morphology: pros and cons of the Toxoplasma-human model in studying the manipulation hypothesis. Journal of Experimental Biology, 216, 127-133.

Flegr, J. (2017). Predictors of Toxoplasma gondii infection in Czech and Slovak populations: the possible role of cat-related injuries and risky sexual behavior in the parasite transmission. Epidemiology and Infection, 145, 1351-1362.

Flegr, J. (2021). Data for the study "Latent toxoplasmosis is associated with a higher level of perceived stress in men but not women, is not associated with anxiety and is associated with worse mental health". . In. Figshare.

Flegr, J., \& Escudero, D. Q. (2016). Impaired health status and increased incidence of diseases in Toxoplasma-seropositive subjects - an explorative cross-sectional study. Parasitology, 143, 1974-1989.

Flegr, J., \& Flegr, P. (2021). Doing exploratory analysis in R with a package Explorer v. 1.0. Figshare. 
Flegr, J., Geryk, J., Volny, J., Klose, J., \& Cernochova, D. (2012). Rhesus factor modulation of effects of smoking and age on psychomotor performance, intelligence, personality profile, and health in Czech soldiers. Plos One, 7, e49478.

Flegr, J., \& Horáček, J. (2020). Negative effects of latent toxoplasmosis on mental health. Frontiers in Psychiatry, 10.

Flegr, J., \& Hrdý, I. (1994). Influence of chronic toxoplasmosis on some human personality factors. Folia Parasitologica, 41, 122-126.

Flegr, J., Kodym, P., \& Tolarová, V. (2000). Correlation of duration of latent Toxoplasma gondii infection with personality changes in women. Biological Psychology, 53, 57-68.

Flegr, J., Novotná, M., Fialová, A., Kolbeková, P., \& Gašová, Z. (2010). The influence of $\mathrm{RhD}$ phenotype on toxoplasmosis- and age-associated changes in personality profile of blood donors. Folia Parasitologica, 57, 143-150.

Flegr, J., Novotná, M., Lindová, J., \& Havlíček, J. (2008). Neurophysiological effect of the $\mathrm{Rh}$ factor. Protective role of the RhD molecule against Toxoplasma-induced impairment of reaction times in women. Neuroendocrinology Letters, 29, 475481.

Flegr, J., Prandota, J., Sovickova, M., \& Israili, Z. H. (2014). Toxoplasmosis - A global threat. Correlation of latent toxoplasmosis with specific disease burden in a set of 88 countries. Plos One, 9.

Flegr, J., \& Preiss, M. (2019). Friends with malefit. The effects of keeping dogs and cats, sustaining animal-related injuries and Toxoplasma infection on health and quality of life. Plos One, 14.

Flegr, J., Sebankova, B., Priplatova, L., Chvatalova, V., \& Kankova, S. (2018). Lower performance of Toxoplasma-infected, Rh-negative subjects in the weight holding and hand-grip tests. Plos One, 13.

Flegr, J., Toman, J., Hula, M., \& Kankova, S. (2020). The role of balancing selection in maintaining human $\mathrm{RhD}$ blood group polymorphism: A preregistered crosssectional study. Journal of Evolutionary Biology.

Flegr, J., Zitkova, S., Kodym, P., \& Frynta, D. (1996). Induction of changes in human behaviour by the parasitic protozoan Toxoplasma gondii. Parasitology, 113, 4954.

Gale, S. D., Brown, B. L., Berrett, A., Erickson, L. D., \& Hedges, D. W. (2014). Association between latent toxoplasmosis and major depression, generalised anxiety disorder and panic disorder in human adults. Folia Parasitologica, 61, 285-292.

Groer, M. W., Yolken, R. H., Xiao, J. C., Beckstead, J. W., Fuchs, D., Mohapatra, S. S., Seyfang, A., \& Postolache, T. T. (2011). Prenatal depression and anxiety in Toxoplasma gondii positive women. American Journal of Obstetrics and Gynecology, 204.

Heretik, A. j., Ritomský, A., Novotný, V., Heretik, A. s., \& Pečeňák, J. (2009). Restandardizace state-trait anxiety inventory X-2 - úzkostnost jako rys. Československá psychologie, 53, 587-599.

Hobfoll, S. E., Dunahoo, C. L., Ben-Porath, Y., \& Monnier, J. (1994). Gender and coping: the dual-axis model of coping. American Journal of Community Psychology, 22, 49-82.

Hodková, H., Kodym, P., \& Flegr, J. (2007). Poorer results of mice with latent toxoplasmosis in learning tests: impaired learning processes or the novelty discrimination mechanism? Parasitology, 134, 1329-1337. 
Kankova, S., Flegr, J., \& Calda, P. (2015). The influence of latent toxoplasmosis on women's reproductive function: four cross-sectional studies. Folia Parasitologica, 62.

Kaňková, Š., Šulc, J., \& Flegr, J. (2010). Increased pregnancy weight gain in women with latent toxoplasmosis and $\mathrm{RhD}$-positivity protection against this effect. Parasitology, 137, 1773-1779.

Kim, S. (2015). ppcor: An R package for a fast calculation to semi-partial correlation coefficients. Communication for Statistical Applications and Methods, 22, 665674.

Lindová, J., Kuběna, A. A., Šturcová, A., Křivohlavá, R., Novotná, M., Rubešová, A., Havlíček, J., Kodym, P., \& Flegr, J. (2010). Pattern of money allocation in experimental games supports the stress hypothesis of gender differences in Toxoplasma gondii-induced behavioural changes. Folia Parasitologica, 57, 136142.

Lindová, J., Novotná, M., Havlíček, J., Jozífková, E., Skallová, A., Kolbeková, P., Hodný, Z., Kodym, P., \& Flegr, J. (2006). Gender differences in behavioural changes induced by latent toxoplasmosis. International Journal for Parasitology, 36, 1485-1492.

Lindová, J., Př́íplatová, L., \& Flegr, J. (2012). Higher extraversion and lower conscientiousness in humans infected with Toxoplasma. European Journal of Personality, 26, 285-291.

Markkula, N., Lindgren, M., Yolken, R. H., \& Suvisaari, J. (2020). Association of exposure to Toxoplasma gondii, Epstein-Barr Virus, Herpes Simplex virus Type 1 and Cytomegalovirus with new-onset depressive and anxiety disorders: An 11year follow-up study. Brain Behavior and Immunity, 87, 238-242.

Markovitz, A. A., Simanek, A. M., Yolken, R. H., Galea, S., Koenen, K. C., Chen, S., \& Aiello, A. E. (2015). Toxoplasma gondii and anxiety disorders in a communitybased sample. Brain Behavior and Immunity, 43, 192-197.

Novotná, M., Havlíček, J., Smith, A. P., Kolbeková, P., Skallová, A., Klose, J., Gašová, Z., Písačka, M., Sechovská, M., \& Flegr, J. (2008). Toxoplasma and reaction time: Role of toxoplasmosis in the origin, preservation and geographical distribution of Rh blood group polymorphism. Parasitology, 135, 1253-1261.

R Core Team. (2018). R: A language and environment for statistical computing. $\mathrm{R}$ Foundation for Statistical Computing. In $R$ : A language and environment for statistical computing. R Foundation for Statistical Computing. Vienna. Austria.

Robertson, J. S. (1965). Toxoplasma skin- and dye-test surveys of severely subnormal patients in Lincolnshire. Journal of Hygiene Cambridge, 63, 89-98.

Rosario, M., Shinn, M., Mørch, H., \& Huckabee, C. B. (1988). Gender differences in coping and social supports: testing socialization and role constraint theories. Journal of Community Psychology, 16, 55-69.

Shin, L. M., \& Liberzon, I. (2010). The neurocircuitry of fear, stress, and anxiety disorders. Neuropsychopharmacology, 35, 169-191.

Shirbazou, S., Abasian, L., \& Meymand, F. T. (2011). Effects of Toxoplasma gondii infection on plasma testosterone and cortisol level and stress index on patients referred to Sina hospital, Tehran. Jundishapur Journal of Microbiology, 4, 167173.

Skallová , A., Kodym, P., Frynta, D., \& Flegr, J. (2006). The role of dopamine in Toxoplasma-induced behavioural alterations in mice: an ethological and ethopharmacological study. Parasitology, 133, 525-535. 
medRxiv preprint doi: https://doi.org/10.1101/2022.01.24.22269770; this version posted January 25,2022 . The copyright holder for this preprint (which was not certified by peer review) is the author/funder, who has granted medRxiv a license to display the preprint in It is made available under a CC-BY-ND 4.0 International license.

Stone, A. A., \& Neale, J. M. (1984). New measure of daily coping: Development and preliminary results. Journal of Personality and Social Psychology, 46, 892-906.

Suvisaari, J., Torniainen-Holm, M., Lindgren, M., Harkanen, T., \& Yolken, R. H. (2017). Toxoplasma gondii infection and common mental disorders in the Finnish general population. Journal of Affective Disorders, 223, 20-25.

Šebánková, B., \& Flegr, J. (2017). Physical and mental health status in Toxoplasmainfected women before and three years after they learn about their infection: Manipulation or side-effects of impaired health? Frontiers in Ecology and Evolution, 5, 144.

Tamres, L. K., Janicki, D., \& Helgeson, V. S. (2002). Sex differences in coping behavior: A meta-analytic review and an examination of relative coping. Personality and Social Psychology Review, 6, 2-30.

Tenter, A. M., Heckeroth, A. R., \& Weiss, L. M. (2000). Toxoplasma gondii: from animals to humans. International Journal for Parasitology, 30, 1217-1258.

Vyas, A., Kim, S. K., Giacomini, N., Boothroyd, J. C., \& Sapolsky, R. M. (2007). Behavioral changes induced by Toxoplasma infection of rodents are highly specific to aversion of cat odors. Proceedings of the National Academy of Sciences of the United States of America, 104, 6442-6447.

Vyas, A., Kim, S. K., \& Sapolsky, R. M. (2007). The effects of Toxoplasma infection on rodent behavior are dependent on dose of the stimulus. Neuroscience, 148, 342-348. 